\title{
Physicochemical and sensory properties of traditional baked cake (kuih bakar) with coconut milk and soy milk
}

\author{
${ }^{1}$ Maimanah-Faizah, I., ${ }^{1}$ Ismail-Fitry, M.R., ${ }^{2}$ Umi Hartina, M.R. and ${ }^{1 *}$ Rozzamri, A. \\ ${ }^{1}$ Department of Food Technology, Faculty of Food Science and Technology, Universiti Putra Malaysia, \\ 43400 UPM Serdang, Selangor, Malaysia \\ ${ }^{2}$ Faculty of Food Science and Nutrition, Universiti Malaysia Sabah, UMS Road, 88400, Kota Kinabalu, \\ Sabah, Malaysia
}

\section{Article history: April 2020 2020 \\ Keywords: \\ Traditional cake, \\ Coconut milk, \\ Soy milk, \\ Physicochemical, \\ Texture, \\ Sensory}

Received: 14 February 2020

Received in revised form: 9

Accepted: 14 April 2020

Available Online: 30 April

DOI:

https://doi.org/10.26656/fr.2017.4(5).068

\begin{abstract}
Coconut milk is widely used in Malaysia as one of the essential ingredients in preparing traditional baked cake or 'kuih bakar'. Increased demand for coconut milk affects its availability and cost. Thus, it is important to study a possible alternative ingredient to ensure the continuity of this traditional dessert. This project aimed to determine the physicochemical and sensory properties of 'kuih bakar' produced with coconut milk and soy milk. In the present study, 'kuih bakar' was prepared with fresh coconut milk (FCM) (positive control), fresh soy milk (FSM), commercial coconut milk (CCM), commercial soy milk (CSM), and without milk (negative control). Proximate analysis showed that substitution of coconut milk with soy milk reduced the fat and increased the protein content of 'kuih bakar' significantly $(p<0.05)$. However, the substitution of coconut milk did not show a significant effect $(p>0.05)$ on the colour properties and water activity of the sample. There were significant differences $(p<0.05)$ in scores during sensory evaluation between the samples but the 'kuih bakar' produced with FSM showed no significant difference $(p<0.05)$ as compared to FCM and CCM. This study demonstrated that physicochemical and sensory attributes of traditional 'kuih bakar' can be maintained by using FSM as a substitution of the traditional coconut milk used in producing 'kuih bakar'.
\end{abstract}

\section{Introduction}

According to the Malaysian Adult Nutrition Survey, local traditional cakes or 'kuih' are among the top ten most commonly consumed food by $14.5 \%$ of Malaysian adults daily (Norimah et al., 2008). The results from the survey show that the daily intake frequency of 'kuih' is 1.15 times with an average of 2 to 3 pieces per day. For the weekly intake, 'kuih' is the fifth most consumed food item among $63.5 \%$ of Malaysian adults with a frequency of 2.19 times and an average of 4 to 5 pieces per week. Overall, 'kuih' is the sixth most frequently taken food in the diet of $92.5 \%$ Malaysian adults with the estimated consumption of $21.6 \mathrm{~g}$ of 'kuih' per day (Norimah et al., 2008).

'Kuih' is a traditional dessert prepared with various ingredients such as wheat flour, glutinous rice, coconut milk, palm sugar, and pandan leaves. One of the wellknown 'kuih' in Malaysia is 'kuih bakar' which is a baked local traditional cake made from wheat flour and coconut milk enriched with pandan and egg flavours and is known for its smoky, caramelized sesame seedencrusted top. The egg is added to help provide the soft and gelling texture of the 'kuih'. The pandan flavour of 'kuih bakar' comes from Pandanus amaryllifolius which is one of the plants that is widely used in South East Asian cooking (Yan and Asmah, 2010). Pandan leaves have a strong aroma and contain natural flavouring and colouring compounds (Loh et al., 2005). The major flavour constituent of pandan leaves that imparts the characteristic pandan flavour and aroma is 2-acetyl-1pyrroline (Thimmaraju et al., 2005). Pandan leaves are also widely used as green colourant for food due to its high chlorophyll content (Loh et al., 2005).

Traditionally, fresh coconut milk has been one of the essential ingredients in preparing 'kuih bakar'. Nevertheless, these days, commercial coconut milk is also widely used due to its convenience and is easy to procure. Fresh coconut milk has lower fat content, higher protein and polyphenol compositions when compared to 
commercial coconut milk (Nadeeshani et al., 2015). Coconut milk is not only known for its rich aroma and flavour but also its high number of health benefits. It contains a high amount of saturated fat that is mainly in the form of medium-chain triglycerides (Pehowich et al., 2000). It also contains lauric acid that has antiviral, antibacterial, and antifungal properties (Raghavendra and Raghavarao, 2010). It was reported that the consumption of coconut milk porridge does not cause a detrimental effect on the lipid profile (Ekayana et al., 2013). Another study also showed that the consumption of fresh coconut milk results in the possibility of prolonged vascular health (Jansakul et al., 2018).

However, the cost of coconut milk has risen drastically over the past few years due to the high demand for the milk which subsequently leads to the insufficient supply of the coconut fruit. According to the Tridge Market Intelligence (2020), coconut production in Malaysia has decreased by $19.2 \%$ since the past 3 years. The wholesale price of MATAG coconut variety which is the most widely grown variety in Malaysia falls at \$18.71 per kilogram (Tridge Market Intelligence, 2020). Thus, due to the current situation of the coconut market, it is important to find an alternative ingredient that can also be utilized in preparing 'kuih bakar'. It is also important for the sustainability of the coconut market.

Soy milk which is produced from soybean seeds has been one of the traditional soy foods in East Asia for several decades (Xia et al., 2019). In the Environmental Nutrition publication, soy milk is more recommended compared to any other non-dairy milk due to its highquality proteins, low saturated fat content, and the absence of cholesterol (McIndoo, 2015; Katz, 2018; Huang et al., 2019). Soy milk is also well known for its high amino acid quality (Abbaspour et al., 2019). The well-balanced amino acid profile of soy milk protein in which it contains all nine essential amino acids makes the milk a significant nutritional foundation to the dietary needs of humans (Singer et al., 2019). While raw soybean protein has poor digestibility due to the presence of endogenous inhibitors of the protein digestive enzymes, protein in soy milk, on the other hand, can be easily digested by the body as the heat treatment destroys most of the inhibitors (Friedman and Brandon, 2001). Soy milk has also been reported as a treatment for dysentery, indigestion, and colic diarrhea (Ladokun and Oni, 2014).

One serving of $240 \mathrm{~mL}$ soy milk contains $99.6 \mathrm{kcal}$ energy, $7 \mathrm{~g}$ protein, $4 \mathrm{~g}$ fat, and $8 \mathrm{~g}$ carbohydrate (Singhal et al., 2017). Soy milk is also a source of fibre, calcium, iron, zinc, and B vitamins. According to USDA FoodData Central (2020), $100 \mathrm{~g}$ of soy milk contains 0.2 $\mathrm{g}$ total dietary fibre, $123 \mathrm{mg}$ calcium, $0.42 \mathrm{mg}$ iron, 0.26 $\mathrm{mg}$ zinc, and $0.031 \mathrm{mg}$ vitamin B6. In addition to that, the soluble dietary fibre found in soy milk also can help in preventing cardiovascular diseases, while progesterone can aid in reducing the symptoms of menopause (Chao, 2008).

For soy milk to be promoted as an alternative ingredient in the preparation of 'kuih bakar', it should not negatively affect or alter the taste and texture of the traditional dessert. Hence, the objective of this study was to determine the effects of using different types of milk on the physicochemical and sensory properties of Malaysian 'kuih bakar'.

\section{Materials and methods}

\subsection{Materials}

Pandan leaves, fresh coconut milk, and fresh soy milk were obtained from a local wet market in Selayang Baru, Selangor. The pandan leaves were cleaned and cut. Commercial coconut milk (Ayam Brand) and soy milk (Home Soy) were purchased from a local supermarket in Kepong, Selangor. The other ingredients required to prepare 'kuih bakar' which are all-purpose wheat flour (Blue Key) that contains $9 \mathrm{~g}$ protein per $100 \mathrm{~g}$ flour, eggs (Nutriplus JUMBO Egg Omega3), coarse sugar (CSR), and coarse salt were purchased from the same supermarket.

\subsection{Physicochemical analysis of different types of milk}

The moisture content, total soluble solids, and $\mathrm{pH}$ of different types of milk, which are fresh coconut milk (FCM), commercial coconut milk (CCM), fresh soy milk (FSM), and commercial soy milk (CSM), were measured using moisture analyzer (Presica, MX120), refractometer (ATAGO handheld), and pH meter, respectively.

\subsection{Preparation of 'kuih bakar'}

The 'kuih bakar' was prepared with different types of milk which are fresh coconut milk (FCM) (positive control), fresh soy milk (FSM), commercial coconut milk (CCM), and commercial soy milk (CSM) as prescribed in Table 1. 'Kuih bakar' without milk was prepared as control (negative control). Pandan leaf juice was obtained by blending the small-cut leaves with water using a blender (Panasonic MX900M). The juice was strained into a bowl to separate any leaf residuals. Then, milk was poured into a pot and cooked over medium heat $\left(70^{\circ} \mathrm{C}\right.$ to $\left.75^{\circ} \mathrm{C}\right)$ for 3 mins. Eggs were beat using a mixer (Mixer COM Taiwan) for 2 mins with the speed of the mixer set at 3 . The other ingredients were added following the formulation in Table 1. A baking mould was greased with cooking oil before the 'kuih bakar' 
Table 1. Formulation of different 'kuih bakar' samples

\begin{tabular}{lccccc}
\hline \multirow{2}{*}{ Ingredients } & \multicolumn{5}{c}{ Quantity (\%) } \\
\cline { 2 - 6 } & Control & FCM & CCM & FSM & CSM \\
\hline Salt & 0.18 & 0.18 & 0.18 & 0.18 & 0.18 \\
Sugar & 15.4 & 15.4 & 15.4 & 15.4 & 15.4 \\
Wheat flour & 15.4 & 15.4 & 15.4 & 15.4 & 15.4 \\
Fresh coconut milk & 0 & 15.4 & 0 & 0 & 0 \\
Commercial coconut milk & 0 & 0 & 15.4 & 0 & 0 \\
Fresh soy milk & 0 & 0 & 0 & 15.4 & 0 \\
Commercial soy milk & 0 & 0 & 0 & 0 & 15.4 \\
Egg & 17.25 & 17.25 & 17.25 & 17.25 & 17.25 \\
Pandan juice & 2.48 & 2.48 & 2.48 & 2.48 & 2.48 \\
Water & 49.29 & 33.89 & 33.89 & 33.89 & 33.89 \\
\hline
\end{tabular}

mixture was poured into it. The mixture was baked in an oven at $250^{\circ} \mathrm{C}$ for 30 mins. The finished 'kuih bakar' was let to cool for $2 \mathrm{hrs}$ before analysis.

\subsection{Proximate analysis}

The moisture content, crude protein content, total fat content, crude fibre content, and ash content were determined for each sample. Moisture content determination was conducted using a moisture analyzer (Presica, MX120). Crude protein content was determined by the micro Kjeldahl method and total fat content was determined according to the Soxhlet extraction method (AOAC, 1990). For crude fibre content determination, acidic and alkaline hydrolysis processes were implemented (AOAC, 1990). Ash content was performed by incinerating the sample in a muffle furnace at $550^{\circ} \mathrm{C}$ for at least $8 \mathrm{hrs}$ until no black particles are present (AOAC, 1990). Carbohydrate content was determined by subtracting 100 with the values of moisture, crude protein, total fat, crude fiber, and ash contents of the sample.

\subsection{Water activity determination}

A water activity analyzer (Decagon Aqualab 3TE) was used to determine the water activity of different samples. Approximately $1 \mathrm{~g}$ of the sample was placed in the drawer of the analyzer. The drawer knob was closed before the measurement started and the reading was recorded.

\subsection{Colour determination}

The colour of different samples was measured using a chromameter (CR-300 Minolta, Japan). $L^{*}, a^{*}$, and $b^{*}$ values were recorded.

\section{$2.7 \mathrm{pH}$ determination}

For $\mathrm{pH}$ determination, $10 \mathrm{~g}$ of each sample was blended with $90 \mathrm{~mL}$ distilled water before a $\mathrm{pH}$ meter (Basic Bench Top pH Meter PB-10, Sartorius, Göttingen,
Germany) was used to determine the $\mathrm{pH}$ of the sample.

\subsection{Textural analysis}

Texture profile analysis (TPA) was performed using a stable microsystem TA-XT2i Texture Analyser (UK). The sample $(25 \mathrm{~mm} \times 25 \mathrm{~mm} \times 25 \mathrm{~mm})$ was axially compressed by a cylindrical aluminum probe $(\varnothing=25$ $\mathrm{mm})$. Each sample was subjected to two-cycle compression at $50 \%$ compression with the probe moving at a speed of $2 \mathrm{~mm} / \mathrm{sec}$ with $30 \mathrm{~s}$ between the first and second compression. Hardness, cohesiveness, adhesiveness, springiness, and chewiness of the sample were determined. Three replicates of measurement were taken for each sample.

\subsection{Sensory evaluation}

Sensory evaluation was carried out by 50 untrained panellists $(n=50)$. Panellists received five different 'kuih bakar' samples which were uniformly sliced. The panellists were instructed to evaluate the aroma, appearance, texture, taste, and overall acceptability of each sample using a five-point hedonic scale ranging from 1 (dislike very much) to 5 (like very much).

\subsection{Statistical analysis}

Each analysis was conducted in triplicates. One-way Analysis of Variance (ANOVA) at a 95\% confidence interval was performed using statistical software Minitab ${ }^{\circledR}$ Release 17, Copyright 2016 (Minitab Inc, Pennsylvania). Differences among the mean values of different samples were measured by Tukey's range test $(p<0.05)$. All the data were reported as mean values \pm standard deviation.

\section{Results and discussion}

\subsection{Physicochemical properties of different types of milk}

The moisture content, total soluble solids, and $\mathrm{pH}$ of different types of milk before added to the 'kuih bakar' sample are shown in Table 2. The moisture content of 
food is often related to its total soluble solids content and may also provide some insight into its dry matter. From this study, the amount of moisture between FSM and CSM showed a significant difference $(p<0.05)$ where FSM appeared to have higher moisture content. These results are similar to research conducted by Ikya et al. (2013). In contrast, there was no significant difference ( $p$ $>0.05)$ between FCM and CCM. This suggests that the processing of CCM does not have any effect on the moisture content as the value is similar to that of FCM.

Table 2. Physicochemical properties of different types of milk before adding to sample

\begin{tabular}{lccc}
\hline \multicolumn{1}{c}{ Milk } & Moisture (\%) & $\begin{array}{c}\text { Total soluble solids } \\
\left({ }^{\circ} \text { Brix }\right)\end{array}$ & $\mathrm{pH}$ \\
\hline FCM & $45.21 \pm 3.77^{\mathrm{c}}$ & $20.28 \pm 0.31^{\mathrm{a}}$ & $6.05 \pm 0.01^{\mathrm{d}}$ \\
CCM & $45.45 \pm 3.25^{\mathrm{c}}$ & $11.33 \pm 0.42^{\mathrm{b}}$ & $6.16 \pm 0.02^{\mathrm{c}}$ \\
FSM & $72.17 \pm 3.73^{\mathrm{a}}$ & $6.40 \pm 0.20^{\mathrm{c}}$ & $6.65 \pm 0.02^{\mathrm{b}}$ \\
CSM & $67.19 \pm 2.57^{\mathrm{b}}$ & $6.33 \pm 0.12^{\mathrm{c}}$ & $6.99 \pm 0.01^{\mathrm{a}}$ \\
\hline
\end{tabular}

Values within the same column with different letters are significantly different $(p<0.05)$

It is apparent from Table 2 that the total soluble solids content of FCM is significantly higher $(p<0.05)$ compared to CCM. A possible explanation for this is that the stabilizer which acts as a preservative added during the processing of CCM might increase the total soluble solids content of the milk. This result is similar to the study done by Wattanapahu et al. (2012) when commercial coconut milk with the different types of stabilizer was studied. However, this outcome is contrary to that of Yalegamma et al. (2009) who found that the total soluble solids in FCM are much lower than those in CCM. This result may be explained by the fact that the various components in FCM might be destroyed due to the heat during the processing. On the other hand, there is no significant difference $(p>0.05)$ in the total soluble solids content between FSM and CSM. This suggests that the freshness of CSM is retained and the ingredient used by the industry does not affect the total soluble solids content. The commercial products are different in total soluble solids content due to the chosen processes depending on the manufacturers.

In this study, the $\mathrm{pH}$ of the milk was also determined. From Table 2, it can be seen that the $\mathrm{pH}$ values for each type of milk are significantly different ( $p$ $<0.05)$. Nevertheless, the values are still in the slightly acidic range, from 6.05 to 6.99 . This range is similar to the $\mathrm{pH}$ values for milk categories stated in a report by the Centre for Food Safety and Applied Nutrition (USFDA, 2007). The $\mathrm{pH}$ is evaluated to determine if commercial products $\mathrm{pH}$ differs from fresh coconut and soy milk.

\subsection{Proximate composition of 'kuih bakar'}

The proximate composition of each sample is shown in Table 3. There is no significant difference found $(p>$ $0.05)$ with the ash content. This indicates that the amount of mineral present in all milk samples that were used is similar. The control sample does not display any significant difference $(p>0.05)$ in ash value indicating that the mineral content of the samples due to the addition of various milk does not vary. Although soy milk and coconut milk contain several minerals such as vitamin B, iron, calcium, and zinc (Chao, 2008), the mineral content in the products might be minuscule to show any adverse effect on the samples.

The value of crude protein content of the sample prepared with FSM showed a significant difference $(p<$ 0.05) when compared to that with CSM. Other samples displayed lower crude protein content (Table 3). When a comparison was carried out between the samples prepared with FCM and FSM, the crude protein content was significantly greater $(p<0.05)$ in the sample prepared with FSM. This finding suggests that by substituting coconut milk with soy milk in preparing 'kuih bakar', the protein content in the traditional dessert could be increased. This explanation is consistent with the study by Belewu and Belewu (2007) who stated that the protein composition in soy milk is greater than that in coconut milk due to its high amino acid quality (Abbaspour et al., 2019). Choonhahirun and Akesowan (2012) also reported the same finding of higher protein in soy milk. Ladukon and Oni (2014) reported that protein content in soy milk was $12.59 \%$ and coconut milk $7.17 \%$ in their fermented form.

The sample prepared with FCM shows a significantly higher $(p<0.05)$ total fat content than that prepared with FSM. This finding is supported by the results from a study by Singhal et al. (2017) who found

Table 3. Proximate composition of 'kuih bakar'

\begin{tabular}{lcccccc}
\hline Sample & Ash (\%) & Protein (\%) & Fat (\%) & Fibre (\%) & Moisture (\%) & Carbohydrate (\%) \\
\hline Control & $0.47 \pm 0.14^{\mathrm{a}}$ & $0.38 \pm 0.16^{\mathrm{d}}$ & $1.79 \pm 0.28^{\mathrm{c}}$ & $0.61 \pm 0.12^{\mathrm{ab}}$ & $63.13 \pm 1.89^{\mathrm{a}}$ & $33.61 \pm 1.59^{\mathrm{c}}$ \\
FCM & $0.54 \pm 0.13^{\mathrm{a}}$ & $0.57 \pm 0.28^{\mathrm{cd}}$ & $9.33 \pm 1.08^{\mathrm{a}}$ & $0.58 \pm 0.07^{\mathrm{ab}}$ & $39.65 \pm 1.33^{\text {cd }}$ & $45.58 \pm 3.72^{\mathrm{b}}$ \\
CCM & $0.70 \pm 0.07^{\mathrm{a}}$ & $1.59 \pm 0.37^{\mathrm{c}}$ & $8.21 \pm 1.33^{\mathrm{ab}}$ & $0.77 \pm 0.09^{\mathrm{a}}$ & $43.14 \pm 2.80^{\mathrm{bc}}$ & $49.33 \pm 0.55^{\mathrm{b}}$ \\
FSM & $0.63 \pm 0.03^{\mathrm{a}}$ & $3.97 \pm 0.32^{\mathrm{a}}$ & $5.18 \pm 1.85^{\mathrm{b}}$ & $0.55 \pm 0.04^{\mathrm{b}}$ & $47.72 \pm 3.29^{\mathrm{b}}$ & $38.22 \pm 3.11^{\mathrm{c}}$ \\
CSM & $0.58 \pm 0.06^{\mathrm{a}}$ & $3.52 \pm 0.68^{\mathrm{b}}$ & $1.37 \pm 0.97^{\mathrm{c}}$ & $0.45 \pm 0.04^{\mathrm{b}}$ & $35.25 \pm 1.72^{\mathrm{d}}$ & $58.83 \pm 1.36^{\mathrm{a}}$ \\
\hline
\end{tabular}

Values within the same column with different letters are significantly different $(p<0.05)$ 
that coconut milk has higher fat content than soy milk. This is related to the high amount of saturated fat present in coconut milk which is medium-chain triglyceride such as lauric acid, compared to soy milk that contains low saturated fat content (Pehowich et al., 2000; Huang et al., 2019). This result further indicates that FSM could replace coconut milk in preparing 'kuih bakar' as the milk does not only increase the protein content but also reduced the fat content in the dessert. This finding also suggests that the fat content in 'kuih bakar' is largely dependent on the type of milk used during its preparation.

It can be observed from Table 3 that the control sample has the highest moisture content value. This result may be explained by the fact that the control sample has the highest amount of water in the formulation. It was also found that the sample prepared with CSM showed a significantly lower $(p<0.05)$ moisture content compared to that of FSM. This is parallel to the result obtained in Table 2 where the moisture content of CSM added is shown to be lower than that of FSM. During baking, heat is induced to the food system which causes water to evaporate and gel structure to form, thus, trapping some water in the gelation network (Lambrecht et al., 2018). This causes changes in the moisture content of the final product.

As Table 3 shows, the sample prepared with CSM has the highest $(p<0.05)$ carbohydrate content of $58.83 \%$ while the control sample has the lowest carbohydrate content of only $33.61 \%$. This might be due to the presence of other additional carbohydrate compounds in the commercial product. The compounds are mainly preservatives such as stabilizers such as xanthan gum and guar gum which are polysaccharides (Nikzade et al., 2012; Góral et al., 2018). Additionally, between samples prepared with FCM and FSM, the sample prepared with FCM showed a significantly greater $(p<0.05)$ carbohydrate value of $45.58 \%$ compared to that value of sample prepared with FSM which is $38.22 \%$. These results may be explained by the fact that coconut milk is composed of both monosaccharides and oligosaccharides whereas soy milk contains glucose, fructose, and fructooligosaccharides (Khuwijitjaru et al., 2012; Preedy, 2014)

\subsection{Physical properties of 'kuih bakar'}

Table 4 shows the water activity, $\mathrm{pH}$, and colour of different samples. As shown in Table 4, no significant difference $(p>0.05)$ can be observed among the water activity values of all samples. The results show that the water activity is above 0.95 which will provide sufficient moisture to support the growth of bacteria, yeasts, and mould in the samples. On the other hand, a statistically significant difference $(p<0.05)$ was recorded when the water activity values of the sample prepared with milk were compared with the control sample (no milk). However, the value which is 0.91 still indicates that the sample is high in water activity. This indicates that the addition of milk causes an increase in water activity. Addition of milk might cause more water retention in 'kuih bakar' as more protein is present which causes gelation and more water to exudate depending on their microstructure and gel formed by globular protein (Lambrecht et al., 2018).

Based on Table 4, it was found that different types of milk used causes a significant change in $\mathrm{pH}$. Before the baking process, the $\mathrm{pH}$ values were in the range of 6.05 to 6.99 . When the $\mathrm{pH}$ of the finished sample was taken after the baking process, slightly lowered $\mathrm{pH}$ values were recorded as shown in Table 4. This result is possibly due to the presence of different compositions of protein, fat, and acidic compounds in different types of milk after heat treatment. According to Renkema et al. (2000) pH value at 7.6 produces fine-strand gels whilst at $\mathrm{pH} 3.8$, more coarse gels are formed. Being in between these $\mathrm{pH}$ might suggest a mixture of intermediate gel texture was formed.

Table 4 also provides an overview of the colour values for different samples. As can be seen from the table, the control sample showed the least $L^{*}$ value. When the $L^{*}$ values of other samples were statistically compared, there is no significant difference $(p>0.05)$ found between them. Similar results are recorded for the $a^{*}$ and $b^{*}$ values for all samples. Thus, this study shows that there is no evidence that the use of different types of milk in preparing 'kuih bakar' would have significant effects on the colour of the traditional dessert. In contrast, Choonhiharun and Akesowan (2012) stated that

Table 4. Physicochemical properties of 'kuih bakar'

\begin{tabular}{lccccc}
\hline \multicolumn{1}{c}{ Sample } & Water activity & $\mathrm{pH}$ & $L^{*}$ & $a^{*}$ & $b^{*}$ \\
\hline Control & $0.91 \pm 0.01^{\mathrm{b}}$ & $6.26 \pm 0.07^{\mathrm{a}}$ & $29.54 \pm 0.01^{\mathrm{b}}$ & $0.68 \pm 0.03^{\mathrm{a}}$ & $-0.99 \pm 0.01^{\mathrm{a}}$ \\
FCM & $0.97 \pm 0.01^{\mathrm{a}}$ & $5.98 \pm 0.07^{\mathrm{c}}$ & $29.76 \pm 0.00^{\mathrm{a}}$ & $0.66 \pm 0.02^{\mathrm{a}}$ & $-0.99 \pm 0.01^{\mathrm{a}}$ \\
CCM & $0.98 \pm 0.00^{\mathrm{a}}$ & $6.01 \pm 0.05^{\mathrm{bc}}$ & $29.76 \pm 0.00^{\mathrm{a}}$ & $0.67 \pm 0.02^{\mathrm{a}}$ & $-0.99 \pm 0.01^{\mathrm{a}}$ \\
FSM & $0.97 \pm 0.00^{\mathrm{a}}$ & $5.96 \pm 0.07^{\mathrm{c}}$ & $29.75 \pm 0.01^{\mathrm{a}}$ & $0.69 \pm 0.03^{\mathrm{a}}$ & $-1.00 \pm 0.01^{\mathrm{a}}$ \\
CSM & $0.96 \pm 0.01^{\mathrm{a}}$ & $6.15 \pm 0.02^{\mathrm{ab}}$ & $29.76 \pm 0.01^{\mathrm{a}}$ & $0.67 \pm 0.05^{\mathrm{a}}$ & $-0.98 \pm 0.01^{\mathrm{a}}$ \\
\hline
\end{tabular}

Values within the same column with different letters are significantly different $(p<0.05)$ 
soy milk has more amine compounds compared to coconut milk such as melanoidins that contribute to brownish red colour. However, the results from the colour analysis in this experiment showed no significant difference.

\subsection{Textural properties of 'kuih bakar'}

Food texture profile analysis involves the application of physical techniques to objectively evaluate the food quality characteristics such as hardness, springiness, cohesiveness, and chewiness. Table 5 shows the experimental data on the textural properties of different samples.

Hardness is expressed as the force required to bite and compress the food between teeth. The hardness values of different samples show a significant difference $(p<0.05)$. Commercial soy and coconut milk displayed significantly higher $(p<0.05)$ hardness compared to fresh and control sample. This indicates a reaction between the substance present in the commercial products such as stabilizers which enhance the hardness of the 'kuih bakar'. This is presented in Table 3, the commercial sample displayed a higher amount of carbohydrate compared to others. Other than that, Goh et al. (2019) reported that increased moisture content causes a decrease in hardness. This is shown when the control sample recorded the significant lowest $(p<0.05)$ hardness due to its high moisture displayed in Table 3. On the other hand, springiness is defined as the degree and quickness of recovery after the compression force was applied to the food. The control sample has the least springiness value (Table 5 ) and the value is significantly different $(p<0.05)$ when compared to that value of the sample added with FCM and CSM. The cohesiveness values of different samples range from 0.53 to 0.73 .
Chewiness recorded a significant difference $(p<0.05)$ for almost all samples indicating that types of milk do affect the chewiness of the product. These results can be explained by the different compositions of protein and types of fat present in coconut milk and soy milk. This might also suggest that the addition of milk increases the springiness and cohesiveness of 'kuih bakar'. On another note, high moisture of control sample as presented in Table 3 might contribute to the soft and rigid texture.

Protein and fat play an important role in providing the texture of baked goods. Baking causes the protein to denature, aggregate and interact with co-protein components to form protein network, thus, providing gelling strength which increases textural properties (Renkema et al., 2000; Lambrecht et al., 2018). Fat crystals trap air bubbles during mixing and as the fat melts during baking, these air is released as gas to produce an aerated structure to finish products, thus, affecting its textural properties (Goh et al., 2019).

\subsection{Sensory properties of 'kuih bakar'}

Table 6 illustrates the sensory properties of different samples. The results from the sensory evaluation display that the samples prepared with FCM and FSM showed no significant difference $(p>0.05)$ on the panellists' overall acceptability. Sample made with FCM shows significantly $(p<0.05)$ highest score in several sensory attributes such as aroma, texture, and taste, thus, resulting in the highest overall acceptability with a score of 4.38. These results may be due to the presence of fresh, creamy, sweet, and nuttiness flavour generated from the volatile compounds such as delta-lactone, noctanol, dodecanoic acid and decanoic acid in FCM (Wattanapahu et al., 2012; Góral et al., 2018). Other than that, the creamy texture of coconut milk is also caused

Table 5. Textural properties of 'kuih bakar'

\begin{tabular}{lcccc}
\hline Sample & Hardness $(\mathrm{g})$ & Springiness (ratio) & Cohesiveness (ratio) & Chewiness $(\mathrm{g})$ \\
\hline Control & $1115.22 \pm 28.17^{\mathrm{d}}$ & $0.63 \pm 0.09^{\mathrm{b}}$ & $0.53 \pm 0.08^{\mathrm{c}}$ & $296.16 \pm 76.74^{\mathrm{d}}$ \\
FCM & $1326.15 \pm 25.41^{\mathrm{bc}}$ & $0.82 \pm 0.09^{\mathrm{a}}$ & $0.62 \pm 0.16^{\mathrm{b}}$ & $725.50 \pm 25.07^{\mathrm{b}}$ \\
CCM & $1396.30 \pm 37.12^{\mathrm{b}}$ & $0.79 \pm 0.01^{\mathrm{ab}}$ & $0.56 \pm 0.03^{\mathrm{c}}$ & $583.00 \pm 5.89^{\mathrm{c}}$ \\
FSM & $1315.41 \pm 22.01^{\mathrm{c}}$ & $0.79 \pm 0.07^{\mathrm{ab}}$ & $0.73 \pm 0.05^{\mathrm{a}}$ & $891.26 \pm 57.21^{\mathrm{a}}$ \\
CSM & $1513.79 \pm 32.04^{\mathrm{a}}$ & $0.88 \pm 0.03^{\mathrm{a}}$ & $0.68 \pm 0.04^{\mathrm{a}}$ & $663.05 \pm 62.63^{\mathrm{bc}}$ \\
\hline
\end{tabular}

Values within the same column with different letters are significantly different $(p<0.05)$

Table 6. Sensory properties of 'kuih bakar'

\begin{tabular}{lccccc}
\hline \multicolumn{1}{c}{ Sample } & Appearance & Aroma & Texture & Taste & Overall acceptability \\
\hline Control & $3.56 \pm 0.97^{\mathrm{b}}$ & $2.96 \pm 1.03^{\mathrm{c}}$ & $3.02 \pm 1.24^{\mathrm{c}}$ & $2.88 \pm 1.19^{\mathrm{c}}$ & $3.02 \pm 1.06^{\mathrm{c}}$ \\
FCM & $3.90 \pm 0.89^{\mathrm{ab}}$ & $4.36 \pm 0.75^{\mathrm{a}}$ & $4.28 \pm 0.61^{\mathrm{a}}$ & $4.30 \pm 0.71^{\mathrm{a}}$ & $4.38 \pm 0.67^{\mathrm{a}}$ \\
CCM & $4.06 \pm 0.77^{\mathrm{a}}$ & $3.58 \pm 0.86^{\mathrm{b}}$ & $3.64 \pm 0.94^{\mathrm{b}}$ & $3.54 \pm 0.93^{\mathrm{b}}$ & $3.74 \pm 0.88^{\mathrm{b}}$ \\
FSM & $4.06 \pm 0.99^{\mathrm{a}}$ & $3.82 \pm 0.96^{\mathrm{b}}$ & $3.98 \pm 0.85^{\mathrm{ab}}$ & $3.76 \pm 1.08^{\mathrm{ab}}$ & $3.90 \pm 0.89^{\mathrm{ab}}$ \\
CSM & $3.98 \pm 0.82^{\mathrm{ab}}$ & $3.48 \pm 0.93^{\mathrm{b}}$ & $3.64 \pm 1.06^{\mathrm{b}}$ & $3.68 \pm 1.04^{\mathrm{b}}$ & $3.70 \pm 0.91^{\mathrm{b}}$ \\
\hline
\end{tabular}

Values within the same column with different letters are significantly different $(p<0.05)$ 
by the increasing size of oil droplet during heating (Wattanpahu et al., 2012). The substitution of FCM with FSM also results in the lack of pandan aroma due to the absence of fat from the coconut milk that protects the volatile compounds that is 2-acetyl-1-pyrroline from the pandan leaves. Fat is known as flavour precursor and flavour carrier that helps distribute the flavour molecules through the food system (Zhao et al., 2018). Despite that, the acceptance towards 'kuih bakar' prepared with FSM is not significantly different $(p>0.05)$ than that of 'kuih bakar' prepared with FCM.

Besides, the overall acceptability of the sample prepared with CCM was rated lower than the sample prepared with FCM. This result is likely due to the loss of most of the volatile compounds in CCM during packaging and storage (Vanga and Raghavan, 2018), causing the sample prepared with the commercial milk to be lacking in the coconut authentic flavour and aroma. On the other hand, the least accepted sample based on the sensory evaluation conducted is the one without milk. The absence of milk results in the lack of flavour that is naturally present in either coconut milk or soy milk.

A comparison between samples prepared with FSM and CSM shows that the one made with CSM obtained lower scores for all the attributes evaluated (Table 6). Previously, some researchers reported that protein in commercial milk will denature during processing, thus, causing the more hydrophobic protein to unfold which will eventually result in the unsatisfied texture of the end -product (Lani et al., 2015). Additionally, other researchers also claimed that commercial milk may cause some negative organoleptic changes towards the food product, resulting in lower scores for aroma and taste attributes (Ma et al., 2016).

Even though the colour (Table 4) and textural (Table $5)$ properties of different samples do not show any significant differences $(p>0.05)$, the appearance and texture scores for some of the samples do show a significant difference $(p<0.05)$ based on the sensory evaluation results. This indicates that the panellists were sensitive enough to detect the changes in the attributes of the famous Malaysian traditional dessert. However, interestingly, the overall acceptability of the panellists towards the sample prepared with FSM is not significant $(p>0.05)$ when compared to the sample with FCM. This confirms that the substitution of FCM with FSM does not affect the sensory perception of the dessert.

\section{Conclusion}

The substitution of coconut milk in 'kuih bakar' resulted in the development of innovated traditional recipe that provides an alternative in the choice of ingredients as coconut is more expensive and becoming a rare commodity. Although 'kuih bakar' is traditionally prepared with coconut milk, this approach offers the development of a different composition of 'kuih bakar' that is low in fat and high in protein. The results of the sensory evaluation show similar acceptance between 'kuih bakar' with FCM and FSM, providing the potential of using soy milk in preparing the dessert as most of the traditional 'kuih bakar' attributes were maintained even with the coconut milk substitution.

\section{Conflict of interest}

The authors declare no conflict of interest.

\section{Acknowledgments}

We would like to extend our appreciation to all the staff from the Food Processing and Biochemistry Laboratories, Faculty of Food Science and Technology, Universiti Putra Malaysia, for their kind assistance throughout this project.

\section{References}

Abbaspour, M., Farajzadeh, M.A., Sorouraddin, S.M. and Mohebbi, A. (2019). Application of a clean-up procedure using a ternary liquid phase system combined with pre-concentration by microextraction in the analysis of seven pesticides from soya milk. Journal of the Science of Food and Agriculture, 99 (8), 4094-4104. https://doi.org/10.1002/jsfa.9639

AOAC. (1990). Official Methods of Analysis of AOAC International. Washington D.C., USA: Association of Official Analytical Chemists.

Belewu, M.A. and Belewu, K.Y. (2007). Comparative physicochemical evaluation of tiger-nut, soybean, and coconut milk sources. International Journal of Agriculture and Biology, 9, 785-787.

Chao, W.X. (2008). Health effects of soy protein and isoflavones in humans. Journal of Nutrition, 138(6), 1244-1249. https://doi.org/10.1093/jn/138.6.1244S

Choonhahirun, A. and Akesowan, A. (2012). Partial fat and sugar replacement with soy milk, inulin and sucralose on quality of Thai Pandanus custard. African Journal of Biotechnology, 11, 46114619.

Ekayana, R.A.I., Ekayana, N.K., Perera, B. and de Silva, P.G.S.M. (2013). Impact of a traditional dietary supplement with coconut milk and soy milk on the lipid profile in normal free living. Journal of Nutrition and Metabolism, 2013, 481068. https:// doi.org/10.1155/2013/481068 
Friedman, M. and Brandon, D.L. (2001). Nutritional and health benefits of soy proteins. Journal of Agricultural and Food Chemistry, 49, 1069-1086. https://doi.org/10.1021/jf0009246

Goh, K.M., Wong, Y.H., Abas, F., Lai, O.M., Cheong, L.Z., Wang, Y., Yoonghua, W. and Tan, C.P. (2019). Effects of shortening and baking temperature on quality, MCPD ester and glycidyl ester content of conventional baked cake. $L W T, 116,108553$. https:// doi.org/10.1016/j.lwt.2019.108553

Góral, M., Kozłowicz, K., Pankiewicz, U., Góral, D., Kluza, F. and Wójtowicz, A. (2018). Impact of stabilizers on the freezing process, and physicochemical and organoleptic properties of coconut milk-based ice cream. LWT, 92, 516-522. https://doi.org/10.1016/j.lwt.2018.03.010

Huang, M.L., Huang, J.Y., Kao, C.Y. and Fang, T.J. (2019). Fermented soy milk and soy and cow milk mixture, supplemented with orange peel fiber or Tremella flava fermented powder as prebiotics for high exopolysaccharide-producing Lactobacillus pentosus SLC 13. Journal of the Science of Food and Agriculture, 99(9), 4373-4382. https:// doi.org/10.1002/jsfa.9671

Ikya, J.K., Gernah, D.I., Ojobo, H.E. and Oni, O.K. (2013). Effect of cooking temperature on some quality characteristics of soy milk. Advance Journal of Food Science and Technology, 5(5), 543-546.

Jansakul, C., Naphatthalung, J., Pradab, S., Yorsin, S. and Kanokwiroon, K. (2018). 6 weeks consumption of pure fresh coconut milk caused up-regulation of eNOS and CSE protein expression in middle-aged male rats. Brazilian Journal of Pharmaceutical Sciences, 54, 1-11. https://doi.org/10.1590/s217597902018000317259

Katz, A.C. (2018). Milk nutrition and perceptions. Rhode Island, USA: Johnson and Wales University, $\mathrm{PhD}$ Dissertation.

Khuwijitjaru, P., Watsanit, K. and Adachi, S. (2012). Carbohydrate content and composition of product from subcritical water treatment of coconut meal. Journal of Industrial and Engineering Chemistry, 18 (1), 225-229. https://doi.org/10.1016/ j.jiec.2011.11.010

Ladokun, O. and Oni, S. (2014). Fermented milk products from different milk types. Food and Nutrition Sciences, 5, 1228-1233. https:// doi.org/10.4236/fns.2014.513133

Lambrecht, M.A., Deleu, L.J., Rombouts, I. and Delcour, J.A. (2018). Heat-induced network formation between proteins of different sources in model systems, wheat-based noodles and pound cakes. Food Hydrocolloids, 79, 352-370. https:// doi.org/10.1016/j.foodhyd.2017.12.032

Lani, M.N., Matsor, N.A.H., Nasution, Z., Ku, P.L. and Yusof, A. (2015). Substitution effects of coconut milk with soy milk on sensory acceptance and shelf life of 'nasi lemak'. British Journal of Applied Science and Technology, 7(4), 377-385. https:// doi.org/10.9734/BJAST/2015/14606

Loh, S.K., Che Man, Y.T., Tan, C.P., Osman, A. and Sheik A., Hamid N. (2005). Process optimization of encapsulated pandan (Pandanus amaryllifolius) powder using spray-drying method. Journal of the Science of Food and Agriculture, 85(12), 1999-2004. https://doi.org/10.1002/jsfa.2169

Ma, X., Hu, X., Liu, L., Li, X., Ma, Z., Chen, J. and Wei, $X$. (2016). The quality changes and microflora analysis of commercial instant soya milk. Food Science and Nutrition, 5(1), 123-130. https:// doi.org/10.1002/fsn3.371

McIndoo, H. (2015). The best plant-based milks. Environmental Nutrition, 38(1).

Nadeeshani, D.L.W.R., Seneviratne, K.N. and Jayathilaka, N. (2015). Determination of nutrient composition of domestic and commercially available coconut milk preparations presented at the Proceedings of the International Postgraduate Research Conference 2015, p. 180. Kelaniya, Sri Lanka: University of Kelaniya.

Nikzade, V., Tehrani, M. M. and Saadatmand-Tarzjan, M. (2012). Optimization of low-cholesterol-low-fat mayonnaise formulation: Effect of using soy milk and some stabilizer by a mixture design approach. Food Hydrocolloids, 28(2), 344-352. https://doi.org/10.1016/j.foodhyd.2011.12.023

Norimah, A.K., Safiah, M., Jamal, K., Haslinda, S., Zuhaida, H., Rohida, S., Fatimah, S., Norazlin, S., Poh, B.K., Kandiah, M., Zalilah, M.S., Wan Manan, W.M., Fatimah, S. and Azmi, M.Y. (2008). Food consumption patterns: Findings from the Malaysian Adult Nutrition Survey (MANS). Malaysian Journal of Nutrition, 14(1), 25-39.

Pehowich, D.J., Gomes, A.V. and Barnes, J.A. (2000). Fatty acid composition and possible health effects of coconut constituents. West Indian Medical Journal, 49(2), 128-133.

Preedy, V.R. (Ed.). (2014). Processing and impact on antioxidants in beverages. USA: Elsevier.

Raghavendra, S.N. and Raghavarao, K.S.M.S. (2010). Effect of different treatments for the destabilization of coconut milk emulsion. Journal of Food Engineering, 97(3), 341-347. https:// doi.org/10.1016/j.jfoodeng.2009.10.027 
Renkema, J.M., Lakemond, C.M., De Jongh, H.H., Gruppen, H. and van Vliet, T. (2000). The effect of $\mathrm{pH}$ on heat denaturation and gel forming properties of soy proteins. Journal of Biotechnology, 79(3), 223 -230. https://doi.org/10.1016/S0168-1656(00)00239$\mathrm{X}$

Singer, W.M., Zhang, B., Rouf Mian, M.A. and Huang, H. (2019). Soybean amino acids in health, genetics, and evaluation. IntechOpen E-Book. Retrieved from InTechOpen website: https://www.intechopen.com/ online-first/soybean-amino-acids-in-health-geneticsand-evaluation

Singhal, S., Baker, R.D. and Baker, S.S. (2017). A comparison of the nutritional value of cow's milk and nondairy beverages. Journal of Pediatric Gastroenterology and Nutrition, 64(5), 799-805. https://doi.org/10.1097/MPG.0000000000001380

Thimmaraju, R., Bhagyalakshmi, N., Narayan, M.S., Venkatachalam, L. and Ravishankar, G.A. (2005). In vitro culture of Pandanus amaryllifolius and enhancement of 2-acetyl-1-pyrroline, the major flavouring compound of aromatic rice, by precursor feeding of L-proline. Journal of the Science of Food and Agriculture, 85(15), 2527-2534. https:// doi.org/10.1002/jsfa.2286

Tridge Market Intelligence. (2020). Overview of coconut market in Malaysia. Retrieved on March 26, 2020 from Tridge Website: https:/www.tridge.com/ intelligences/coconut/MY

United States Department of Agriculture (USDA) FoodData Central (FDC). (2020). Soy milk. Retrieved on March 27, 2020 from FDC Website: https://fdc.nal.usda.gov/fdc-app.html\#/fooddetails/336099/nutrients

United States Food and Drug Administration (USFDA). (2007). Approximate $\mathrm{pH}$ of foods and food products: Acidified and low-acid canned food. Maryland, USA: USFDA.

Vanga, S.K. and Raghavan, V. (2018). How well do plant-based alternatives fare nutritionally compared to cow's milk? Journal of Food Science and Technology, 55, 10-20. https://doi.org/10.1007/ s13197-017-2915-y

Wattanapahu, S., Suwonsichon, T., Jirapakkul, W. and Kasermsumran, S. (2012). Categorization of coconut milk products by their sensory characteristics. Kasetsart Journal (Natural Science), 46, 944-954.

Xia, J., Zu, Q., Yang, A., Wu, Z., Li, X., Tong, P., Yuan, J., Wu, Y., Fan, Q. and Chen, H. (2019). Allergenicity reduction and rheology property of Lactobacillus-fermented soy milk. Journal of the Science of Food and Agriculture, 99(15), 6841-
6849. https://doi.org/10.1002/jsfa.9969

Yalegamma, L.L.W.C., Ambigaipalan, P. and Arampath, P.C. (2009). Physico-chemical and shelf life evaluation of pasteurized coconut milk. Indian Coconut Journal, 52, 16-21.

Yan, S.W. and Asmah, R. (2010). Comparison of total phenolic contents and antioxidant activities of turmeric leaf, pandan leaf and torch ginger flower. International Food Research Journal, 17, 417-423. 